\title{
The early Holocene ice-dammed lake Nedre Glomsjø in Mid-Norway: an open lake system succeeding an actively retreating ice sheet
}

\author{
Fredrik Høgaas' ${ }^{1} \&$ Oddvar Longva' \\ ${ }^{1}$ Geological Survey of Norway, P.O. Box 6315 Torgarden, NO-7491 Trondheim, Norway. \\ E-mail corresponding author (Fredrik Høgaas): fredrik.hogaas@ngu.no
}

\begin{abstract}
The existence of large late-glacial ice-dammed lakes in Mid-Norway was recognised in the late 1800s. Mapping of the lakes' distribution provided novel and valuable information regarding ice age palaeogeography and glacial isostatic adjustment, but the findings failed to convince the scientific community at the time. Divergent opinions concerning the inland lakes have lingered to the present, in particular as the purported glacial lake shorelines have been interpreted as subglacial or lateral meltwater features. In this study we revisit the largest palaeolake - glacial lake Nedre Glomsjø - and attempt to unravel the controversy using high-resolution airborne LiDAR data. Our mapping has revealed key and hitherto undescribed landforms indicative of an open lake system. De Geer moraines signal that the ice sheet retreated in a water-body corresponding to the elevation of the Nedre Glomsjø shorelines. The De Geer moraines also determine that the ice sheet in the region did not merely melt vertically down, but rather retreated actively southward, and we thus refute studies claiming that the purported shorelines formed along a closed ice-filled basin with stagnant ice. Based on the number of De Geer moraines, the ice-sheet margin is estimated to have retreated step-wise through our study area at a rate of 200-600 $\mathrm{m} \mathrm{yr}^{-1}$. The study highlights the potential of mapping glacial lake remnants for assessing palaeoglaciology in an ambiguous sector of the Scandinavian Ice Sheet.
\end{abstract}

Keywords: The Scandinavian Ice Sheet, Deglaciation, Holocene, Nedre Glomsjø, Proglacial lake

Received 19. June 2018 / Accepted 18. December 2018 / Published online 24. February 2019

\section{Introduction}

Ice-dammed lakes early attracted the attention of research in Norway (e.g., Hansen, 1886; Rekstad, 1912; Holmsen, 1915), but represent today an under-studied, although potentially valuable subject in relation to ice age palaeogeography (e.g., Hughes et al., 2016). The distribution and nature of ice-dammed lakes, and traces of potential outburst floods, can provide information on deglaciation patterns in areas where little is known and few absolute dates exist (Lundqvist, 1972; Jansson, 2003; Høgaas \& Longva, 2016; Stroeven et al., 2016). Glacial lakes were for instance one of the founding pillars when Hansen (1892) constructed an early and impressively accurate ice-divide for the Norwegian sector of the
Scandinavian Ice Sheet. To be employed in such contexts, it is pivotal to learn more about the lakes' environment and whether the lakes were vast proglacial lake systems or smaller, more local ponds formed along a stagnant and dynamically dead ice sheet.

The glacial lake Nedre Glomsjø (Holmsen, 1915) was a large inland lake which formed between the receding ice sheet and the main water divide at the end of the last Ice Age (Fig. 1). Continuous terraces and lines were thought to be shorelines (no: sete/såttå) formed along the glacial lake, and, hence, to prove its existence. The shorelines were graded toward the spillway at Rugldalen situated at $c .665 \mathrm{~m}$ asl. The lake is believed to have covered an area larger than $1500 \mathrm{~km}^{2}$ (Holmsen, 1915) and holding a water volume of $100 \mathrm{~km}^{3}$ (Longva, 1994). As a

Høgaas, F. \& Longva, O. 2018: The late-glacial ice-dammed lake Nedre Glomsjø in Mid-Norway: an open lake system succeeding an actively retreating ice sheet. Norwegian Journal of Geology 98, 661-675. https://dx.doi.org/10.17850/njg98-4-08. 


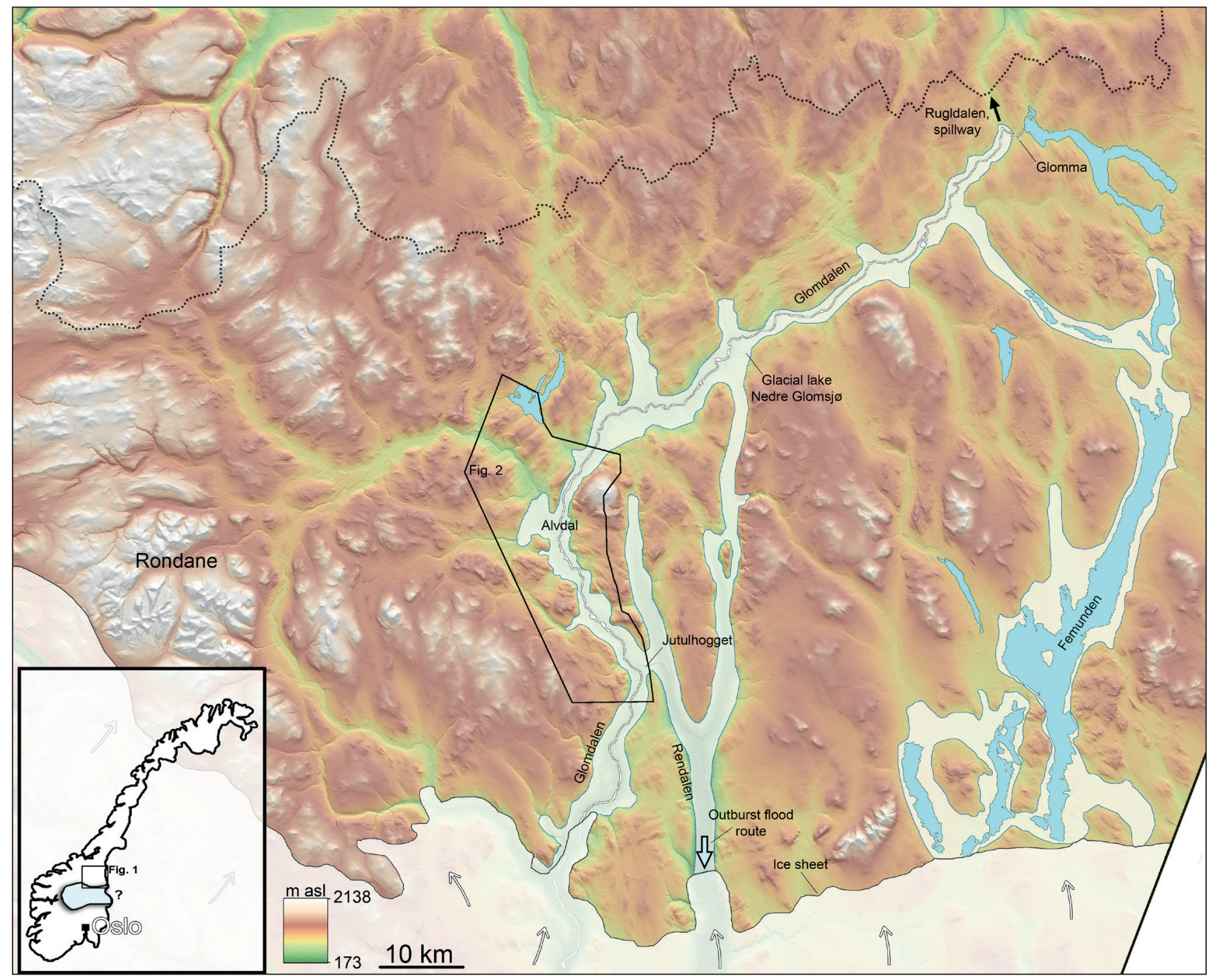

Figure 1. Digital elevation model of the study area with the glacial lake Nedre Glomsjø outlined. The ice lake's extent and ice-sheet margin are adapted from Holmsen (1915). The lake extended a few $\mathrm{km}$ farther south in both Rendalen and Glomdalen. A tentative remnant ice margin is shown in light blue colour in the inset map. The dotted line indicates the regional drainage divide.

comparison, Norway's largest lake - lake Mjøsa - covers an area of $365 \mathrm{~km}^{2}$ and holds a water volume of $c .56 \mathrm{~km}^{3}$ (Pettersson, 1997). When a subglacial passage through the remnant ice sheet was established, a large portion of Nedre Glomsjø drained catastrophically in a matter of weeks at around 10-10.4 cal ka BP (Longva, 1994). The outburst flood led to extensive erosion and deposition of vast fine-grained slack-water deposits and large bar landforms in the affected region south of the ice sheet (Longva, 1984, 1994; Høgaas \& Longva, 2016). Where the flood emerged at the southern fringe of the ice sheet, the flood wave was 85-95 m deep and several kilometres wide (Høgaas \& Longva, 2016).

The purpose of this paper is to shed new light on a classic topic - ice-dammed lake Nedre Glomsjø - and to assess whether the related landform record may provide information on regional ice-sheet decay and the palaeolake's physical environment. Our area of focus has been a small part of the former inundated area (Figs. 1 \& 2). We have applied high-resolution airborne LiDAR data to map key landforms seen in relation to the former ice-lake, which provide an unprecedented basis for interpreting the late-glacial environment in the region. The geological record suggests that the landforms were formed in an open lake system directly succeeding an actively retreating ice-sheet margin.

\section{Regional deglaciation}

There are very few absolute dates which constrain the deglaciation of this area. A study just north of lake Savalen (Fig. 2) suggest an early deglaciation age (16 ka BP) of the ice sheet in the region, based on sediments in a high-altitude lake (Paus et al., 2006). The age was found by extrapolating the lowermost dated samples (yielding 10.7-10.8 cal ka BP) based on accumulation 


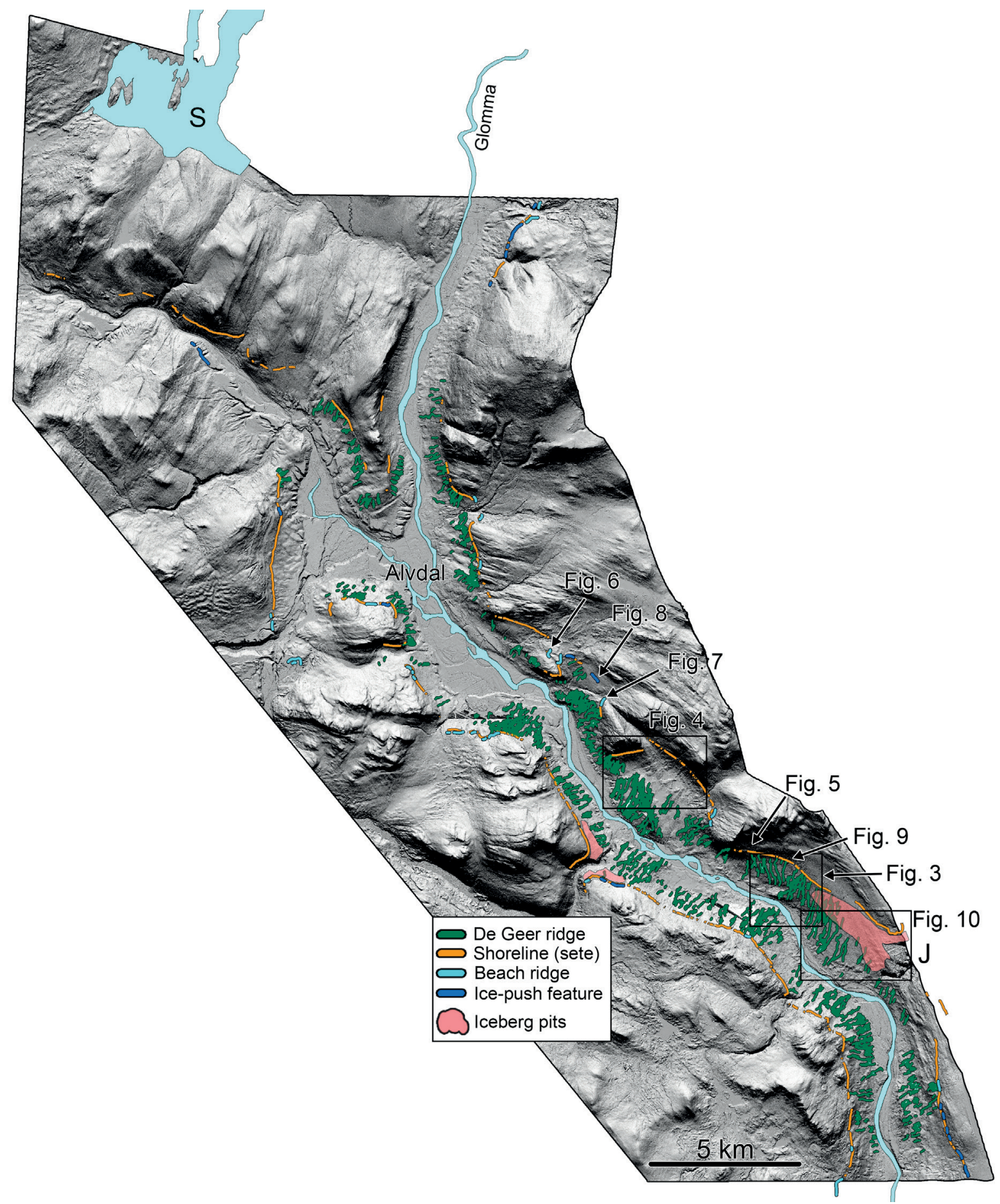

Figure 2. Study area with mapped landforms and features related to the Nedre Glomsjø ice-lake. Abbreviations: J - Jutulhogget canyon, S Savalen.

rates of pollen found in the core. In the coastal areas to the northwest, a robust deglaciation chronology based on radiocarbon dates and geomorphological mapping revealed that the coastal-to-inner fjord region became ice-free at around 15-11 cal ka BP (Reite, 1994; Rise et al., 2006; Olsen et al., 2015). Exposure dates in the mountainous area east of lake Femunden (Fig. 1) suggest rapid thinning of the ice sheet around the Younger Dryas-Holocene boundary. The study was unable to fully resolve the timing of deglaciation, but concluded that the ice sheet was situated below $880 \mathrm{~m}$ prior to 10 ka (Goehring et al., 2008). Taken together, this suggests that our study area was deglaciated sometime around 11-10 ka, which is supported by the deglacial time-slice reconstructions from Hughes et al. (2016) and Stroeven et al. (2016).

Another approach to estimating regional deglaciation ages is interpretation of sediments in the outburst flood's impact area south of the ice sheet, as the vast sediment 
delivery covered large areas of land. Radiocarbon dating of sediment-covered organic matter in the flood inundated areas suggest the event occurred at around 10-10.4 cal ka BP (Longva, 1994; Høgaas \& Longva, 2016). This age span can accordingly be used as a minimum-limiting deglaciation age for the glacial lake area and further supports an early Holocene deglaciation age.

\section{Research history, glacial lake Nedre Glomsjø}

Whether the purported shorelines seen in the region were formed in an open lake or not has been a debated topic. Initially, however, it was the location of the glacial dam itself - and whether or not such a dam existed - that generated the biggest debate. Hansen (1886) mapped and measured shorelines in the region and suggested the features were formed in a large inland lake dammed by a remnant ice sheet situated in the central parts of Norway. Hansen later $(1890,1892)$ paired his inland glacial lake shorelines with coastal shoreline observations and developed his novel theories of a large continental ice sheet - about simultaneously as De Geer's $(1888,1890)$ classic studies in Sweden.

Hansen's ice-sheet theory (1886) endured severe criticism, as it implied that the glaciers had to move up-slope towards the water divide. At that time, the consensus was that the glaciers had formed in the highlands and flowed downwards. Also, when the glaciers melted the valleys would become ice-free first. Leaving a remnant ice sheet in the relatively low-lying central, eastern parts of Norway, like Hansen (1886) did, was thus found to be absurd (Schiøtz, 1891; Reusch, 1894, 1910). Although the theory was in stark conflict with the reigning view, Hansen's (1886) proposed ice-divide had some support (although not voiced) in erratic and northerly oriented striation mark observations (Hørbye, $1855,1857,1859)$.

Some authors regarded the purported shorelines as lateral moraines (e.g., Reusch, 1886; Blytt, 1891), but as it was acknowledged that many of the horizontal lines probably were shoreline features, the focus shifted to explain where the damming ice mass had propagated from. The common view in that matter was that an ice lobe flowing down from the Rondane highlands (Fig. 1) dammed the drainage, allowing Nedre Glomsjø (and other, more local ice-dammed lakes) to form (Rekstad, 1898; Øyen, 1899). According to Rekstad (1912), however, the lake was "not as big as Hansen claimed it was".

It was not until Holmsen's study (1915) that Hansen's views gained some weighty support. By describing and levelling shoreline features at different elevations through three seasons and relating the observations to local and regional drainage divides, Holmsen proposed that vast lakes had been dammed by the remnant ice sheet. The largest - ice-lake Nedre Glomsjø - was estimated to have covered a 1500-1600 $\mathrm{km}^{2}$ large area (Holmsen, 1915, p. 133). He also found that the shorelines generally were sloping down in a westerly direction and related this (somewhat vaguely) to differential uplift of the land. Nearly all his results spoke in favour of Hansen's (1886) early hypothesis.

Reusch (1917) recognised Holmsen's (1915) study as thorough work, but again rejected the idea of large open lakes. He suggested that the shoreline features were icemarginal moraines - or rather soliflucted till that had been transported down to the glacier and later altered by running water. The features were thus formed by erosion by water bodies situated on top of the shrinking ice sheet, and by small streams that connected these ponds (Reusch, 1917). Holmsen (1956) later curbed his own theory of a vast, open, Nedre Glomsjø glacial lake and acknowledged that there probably was a large amount of glacial ice still situated in the valleys.

Gjessing (1955, 1960) provided an entirely new perspective in the late 1950s, as he pointed to subglacial meltwater drainage as the origin for the purported shorelines. No open lakes had existed, and the lines were rather formed as the water pressure lifted the ice as a whole and a state of subglacial sheet-like drainage was obtained. The elevation of the 'shorelines' was thus governed by, and graded to, the height of the runoff passes (Gjessing, 1955, 1960). He later echoed his views (Gjessing, 1965), despite facing criticism from his opposition (Holmsen, 1960a, b; Holmsen, 1967; Holtedahl, 1960; Hoppe, 1960). Regardless of the criticism, Gjessing's theory did offer an explanation to the seemingly undisturbed spillway areas, like Rugldalen (Fig. 1), where eskers and loosely consolidated deposits show no indication of a large-scale subaerial drainage (Gjessing, 1955, 1960, 1965).

Sollid (1964) argued that the formation of the continuous lines were due to erosion from ice-directed meltwater drainage and Gjessing (1960) was thus given some support. Sollid, too, pointed to the ambiguous run-off passes as important proof when rejecting the large open ice-lake theory. Unlike Gjessing, however, he did not emphasise a sheet-like subglacial drainage, but argued that the erosion could have taken place both supra- and subglacially. Follestad (1997) (and partly Follestad \& Thoresen, 1999) supported Gjessing's (1960) subglacial waterway theory and could, much like Reusch (1917), only acknowledge "short intervals of subaerial, lateral ice-lake conditions" (Follestad, 1997, p. 51) in the region. This was partly based on an extensive stripping of sediment - a 'flushed' zone - above the purported shorelines (Follestad, 1997, 2003). This characteristic feature was also noted by the early pioneers, who pointed out a conspicuous difference between the terrain above and below the highest shoreline (Hansen, 1886; Holmsen, 1915). Hence, according to Follestad (2003, p. 2), the 
only feasible explanation for the shorelines' presence must have been "violent glaciofluvial activity between the hillside and a passive remaining glacier or inland ice".

At the time of Follestad's contributions (1997, 2003), there were already some studies that pointed to the occurrence of fine-grained sediments, beach ridges and delta structures in the region and these were highlighted as clear indications of a partly open lake system (Holmsen, 1915; Andersen, 1969; Østeraas, 1977; Sollid \& Kristiansen, 1983). This interpretation was later supported by geophysical and sediment rounding surveys on the landforms in question (Tønnesen \& Olsen, 2015). An idea of an open glacial lake system - at least in the final stages - is generally accepted today and is also supported by the authors of the present paper.

When the vast ice lake drained, the majestic Jutulhogget canyon (Schetelig, 1910; Holmsen, 1943) was carved to its present shape by the rushing floodwaters. However, it is reasonable to assume a polygenetic evolution of the canyon, having formed during a span of several Ice Ages (Longva, 1994). At the canyon mouth, a large, coarsegrained, bar feature - Raneggen/Fallegga - was deposited during the jökulhlaup (Holmsen, 1949; Holmsen \& Oftedahl, 1956). The bar is more than $100 \mathrm{~m}$ thick locally (Hillestad, 1991) and is scattered with mega-boulders larger than $100 \mathrm{~m}^{3}$.

It is believed that the ice-dammed lake drained underneath (and within?) the ice sheet until a steadystate drainage over the Jutulhogget threshold (c. $510 \mathrm{~m}$ asl) could be maintained (e.g., Østeraas, 1977). Berthling \& Sollid (1999) mapped several shorelines between the Nedre Glomsjø level and the Jutulhogget lake level and suggested a more complex, successive emptying of the glacial lake, like Liestøl (1956) had suggested earlier. This, however, has not yet been traced in the flood-related deposits south of the ice sheet (Longva, 1994; Høgaas \& Longva, 2016).

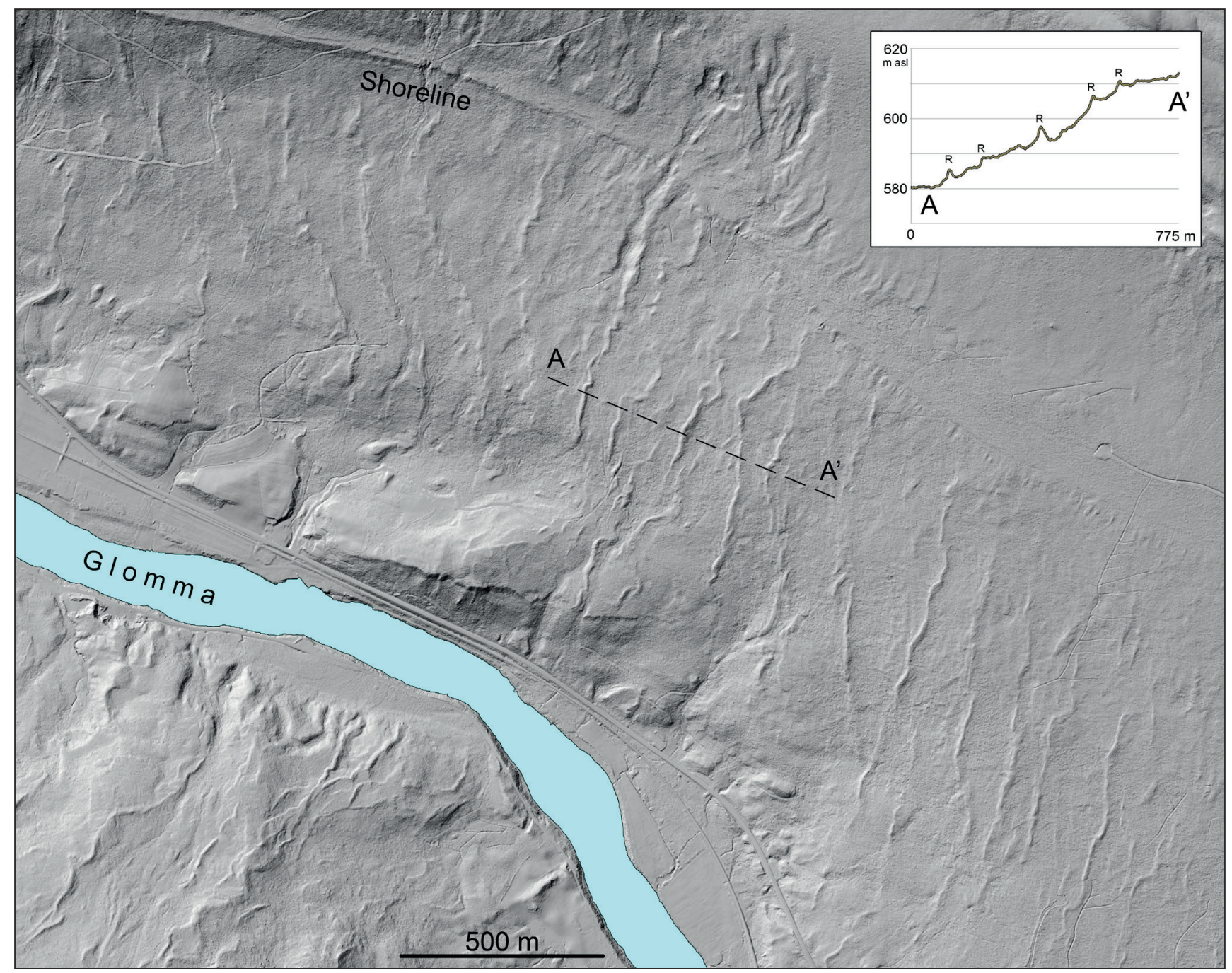

Figure 3. Excerpt from the valley floor near Jutulhogget, where we have mapped multiple De Geer moraine ridges ( $R$ in the terrain profile). 


\section{Methods}

We apply the airborne LiDAR dataset Alvdal from the national detailed terrain model $(\mathrm{NDH})$ scanning. The resolution of the dataset varies from an average of 5 points $/ \mathrm{m}^{2}$ in central Glomdalen to 2 points $/ \mathrm{m}^{2}$ in the periphery of the study area. Using the LiDAR ground point data we gridded high-resolution DEMs of $1 \mathrm{~m}$ pixel size covering the entire study area. Grey-scale hillshade (shaded relief) images with solar azimuths (directions) of $315^{\circ}, 45^{\circ}$ and $360^{\circ}$ were subsequently processed from the DEMs. Two additional hillshade images with solar azimuths of $315^{\circ}$ and $360^{\circ}$ were given a considerable digital terrain exaggeration ( $\mathrm{z}$ factor 3 ). All images are rendered with a solar angle of $45^{\circ}$. The floating-point raster models were used for extracting elevation data and provided the basis for constructing terrain profiles. Geomorphological mapping was carried out in ESRI ArcGIS using the shaded-relief images. Relevant features were carefully traced and compiled into lines, points and polygons in a georeferenced database.

Field reconnaissance was carried out in the autumn of 2017. The overall aim of the field trip was to obtain ground-truth data, i.e., make sure that subtle terrain features were indeed visible and not digital artefacts.

\section{Assemblage of landforms associated with the glacial lake Nedre Glomsjø}

We have distinguished several different landforms that aid our interpretation of the late-glacial environment in the area (Fig. 2). The geomorphological record comprises ice-marginal moraines, iceberg pits and features that we assumed were developed near-shore in a littoral zone.

\section{De Geer moraines}

De Geer moraines are moraine ridges formed at the grounding line of a water-terminating glacier (Lindén \& Möller, 2005). De Geer moraines occur throughout the study area (Figs. $2 \& 3$ ), save for the northernmost part. The moraines are commonly seen as asymmetric, wedgelike deposits with a frontal ridge. The ridges are sharpcrested and narrow, typically less than $20 \mathrm{~m}$ across, and have an amplitude of 1-4 $\mathrm{m}$. The De Geer moraines are oriented transverse to the valley and occur 50-250 m apart. The moraines extend up to the shorelines we have mapped in this study and are not in a single instance seen above this level. This matches with studies in western and northern Norway, where De Geer moraines have been traced up to the contemporary late-glacial shoreline (Sollid \& Carlsson, 1984; Larsen et al., 1991).

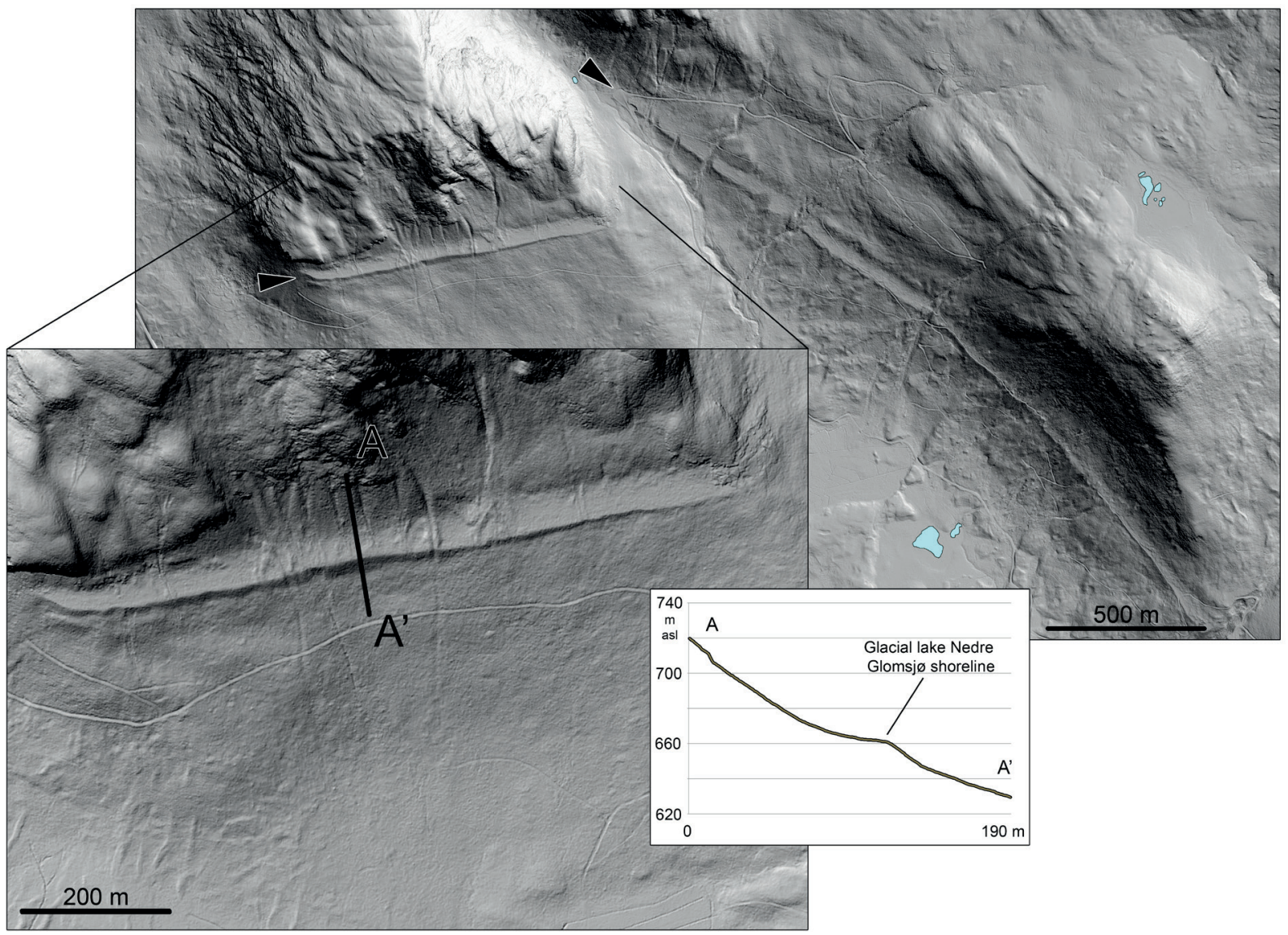

Figure 4. Examples of shoreline segments stemming from the glacial lake Nedre Glomsjø. Black triangles highlight the shorelines. 
We interpret the De Geer moraine record to fingerprint a receding ice-sheet margin with a calving bay configuration. We have mapped more than 1600 De Geer moraine segments within the study area. Naturally, many of these are isochronous and represent the same halt in the receding glacier margin. By looking at the eastern side of the valley only, we conservatively estimate more than 180 individual moraine systems - i.e., moraines formed time-transgressively. A contrasting explanation for the distinct ridges is that they are subglacially engorged eskers. We reject this idea for our study area, as the moraines are seen to bend down-valley. If they were to represent conduit systems within the glacier, they would follow the hydrostatic pressure in the former ice sheet and thus bend up-valley (north).

\section{Shorelines}

We define the entire morphologically visible level - from the shore slope to the inner break - as the glacial lake's shorelines, regardless of whether the formation is due to erosion or deposition of material. The conspicuous shorelines (Figs. 4 \& 5) generally persist for several km and are seen along the valley sides throughout the entire study area, except for in the steepest parts of the valley (Fig. 2). Due to postglacial isostatic adjustment, the shorelines are found at different elevations throughout the study area, i.e., c. $655 \mathrm{~m}$ asl in the north, to c. 666 $\mathrm{m}$ asl around the Jutulhogget canyon in the south. The valley floor is located 170-200 m below this level. Above the shore slope a relatively flat terrace rises typically 6-10 $\mathrm{m}$ up to the inner break. Shoreline widths of 30-40 $\mathrm{m}$ are common, but some sections are locally more than $50 \mathrm{~m}$ wide, e.g., parts of the shorelines seen in Fig. 4.

Using the LiDAR-derived images, the shorelines stand out from the surrounding terrain as smooth continuous terraces (Figs. 4 \& 5). Lateral meltwater action can produce similar imprints along a stagnant dead-ice body, but these are rarely more than a few hundred metres long and usually terminate with a downslope, subglacial trend.

\section{Beach ridges}

We have mapped more than 30 berm-like features located on the Nedre Glomsjø shoreline. The amplitude is typically $0.2-0.5 \mathrm{~m}$, and in all cases less than $1.5 \mathrm{~m}$. The subdued landforms, which commonly occur as multiple ridges at different elevations, stretch along the terrain contour at 3-8 $\mathrm{m}$ above the glacial lake's shore slope (Figs. 6 \& 7). We interpret the curved and slightly elevated features as beach ridges and further believe that these attest to ice-free periods when material could be heaved up by wave action.

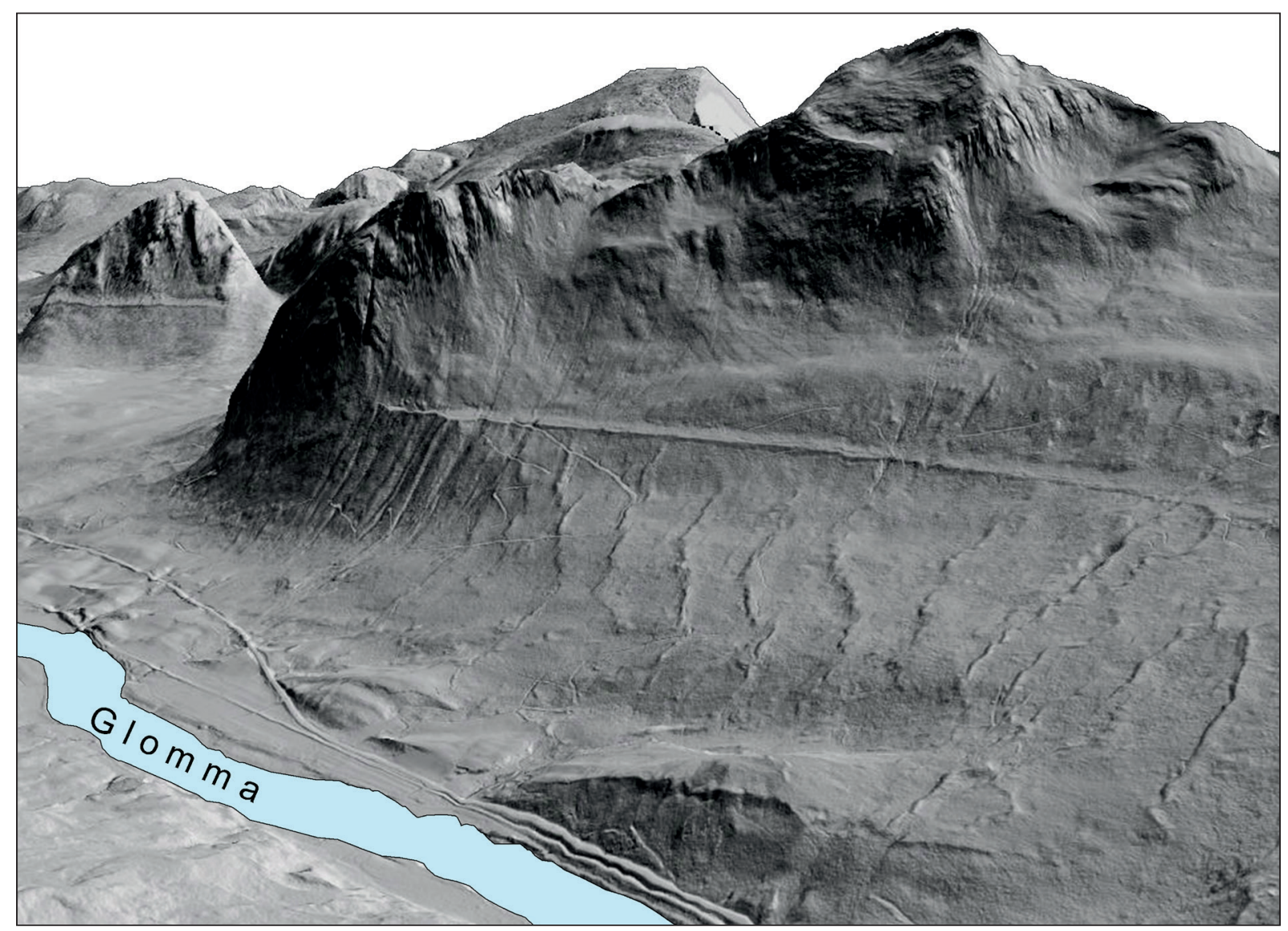

Figure 5. Oblique view of De Geer moraines and the Nedre Glomsjø shoreline. Terrain exaggeration factor 2x. View towards the north. 


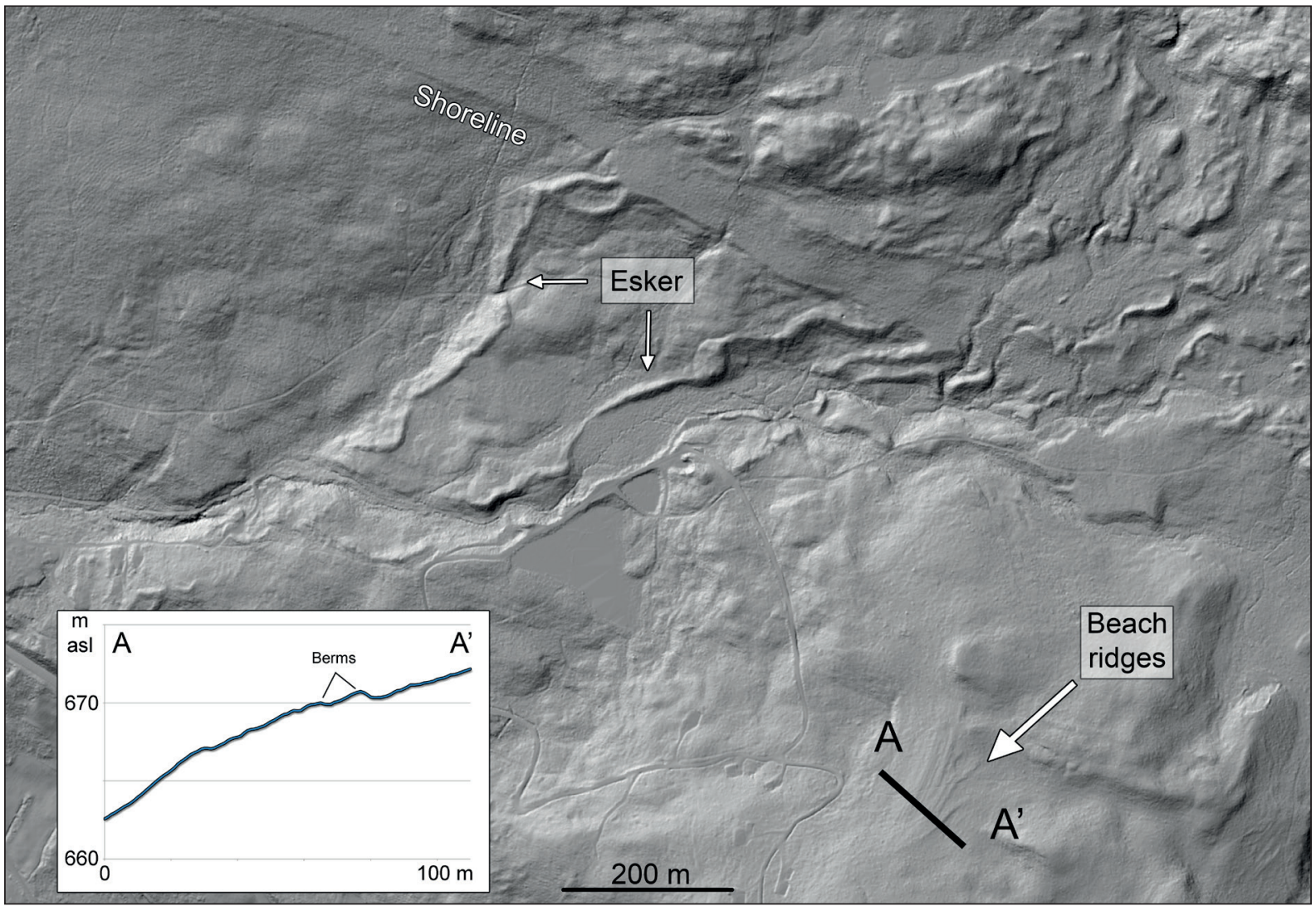

Figure 6. Shaded relief image showing a Nedre Glomsjø palaeo-bay with beach ridges near Alvdal. Note that the cascading esker systems are truncated by the Nedre Glomsjø shoreline, thus indicating a clear chronological relationship between the landforms.

The beach ridges visited in the field vary from $0.2-0.5$ $\mathrm{m}$ in height and consist of well sorted, often angular to subangular cobbles. The local sandstone weathers easily and the schistosity results in angular rather than rounded particles. It is thus unclear whether the cobble bed is a product of sorting in a littoral zone along the ice-lake or if it is due to diffusion of a local weathering product.

\section{Ice-push features}

We have included some specific structures found on the Nedre Glomsjø shorelines (Figs. 8 \& 9). The structures are small and irregular scars or berms that occur just above the shore slope. The berms seem too chaotic in terms of morphology and distribution to be viewed as beach ridges. All features are subtle landforms, as the profile across the small notch in Fig. 8 suggests. The ridge seen close to the notch in Fig. 8 stands out as an irregular berm $<0.5 \mathrm{~m}$ high. In the field, the features appear as small, $c .0 .2-0.4 \mathrm{~m}$-high, notches or scars in the terrain. Other notches are more prominent and are backed by a locally 1-3 m-high wall on the shoreline terraces (Fig. 9). During field reconnaissance we have also observed 'paved shorelines', where rocks and cobbles have been pressed together and occasionally risen vertically.
All features are found unequivocally on the shoreline terraces and we see accumulated and erosive features adjacent to one another. We interpret the features as having been formed by ice-push mechanisms from lake ice and term the subtle landforms ice-push features. Typically, features formed due to ice-push mechanisms are much larger, but small-scale relief associated with icepush along marine and terrestrial shorelines have been reported from arctic environments (e.g., Dionne, 1979, 1992). The ice-push features signal the presence of lake ice in the basin.

\section{lceberg pits}

We have also mapped conspicuous pit-like depressions in the terrain (Figs. $10 \& 11$ ). They appear in large clusters in a few locations within our study area (Fig. 2), but are particularly prominent and visible close to the Jutulhogget canyon. The depressions vary in size and shape, but are usually $0.5-3 \mathrm{~m}$ deep and fairly circular, although more extended depressions do occur. We interpret the depressions as pits inflicted by stranded icebergs.

Close to Jutulhogget, the depressions' morphology and appearance somewhat change. Here, the pits are 


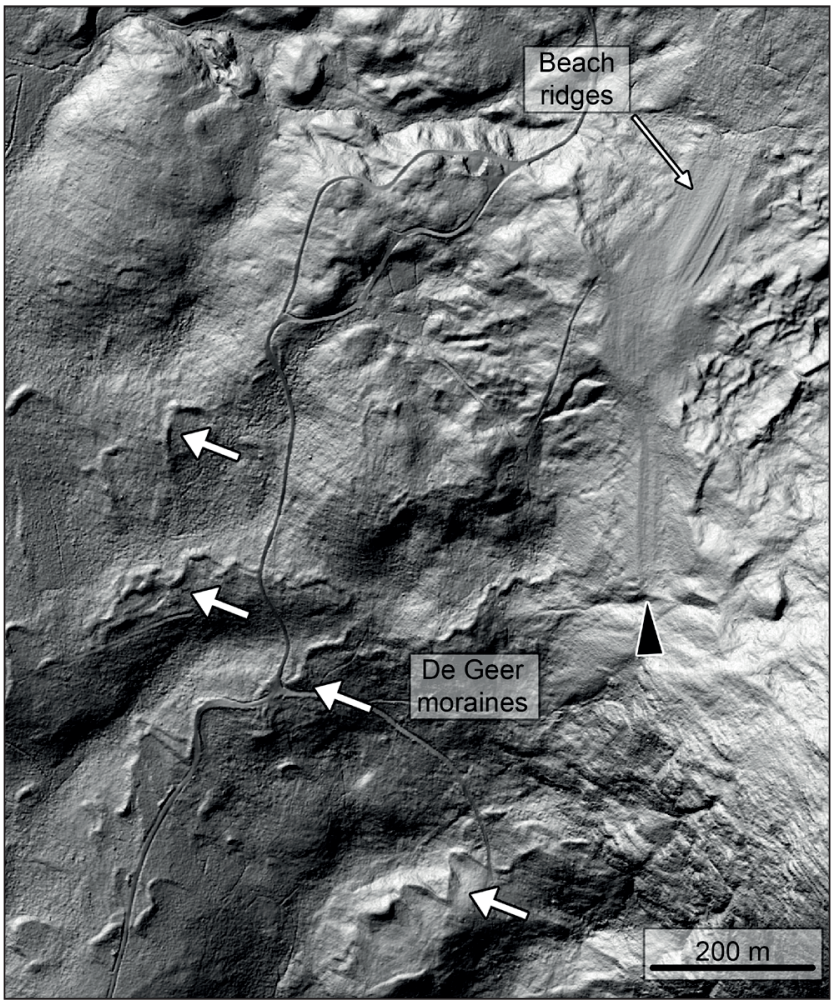

Figure 7. Distinct beach ridges and De Geer moraines. The glacial lake's shoreline is indicated with a black triangle. succeeded by a straight scour or ridge, which generally are 'pointing' toward the gorge, displaying a funnel-like pattern (Fig. 11). Because of this, we believe the pits formed as icebergs stranded as they were drawn toward the canyon when the outburst flood commenced. The scours and ridges resemble ice-block obstacle marks, which are formed due to differential flow and deposition around and near a flow obstacle (Russell, 1993). Such features have been reported from jökulhlaup deposits on Greenland and Iceland (Russell, 1993; Fay, 2002) and are also seen on top of flood bars deposited during the Nedre Glomsjø outburst flood (Høgaas \& Longva, 2016).

\section{Discussion}

Ice-sheet dynamics and retreat rates in the Nedre Glomsjø basin

Berthling \& Sollid (1999) pointed to the presence of De Geer moraines as an indicator of a calving ice margin in Glomdalen. Our thorough and complete mapping of De Geer moraines in the area (Fig. 2) supports this and shows that the ice sheet actively retreated southward, rather than merely melting vertically down. The moraines also established the presence of multiple ice-

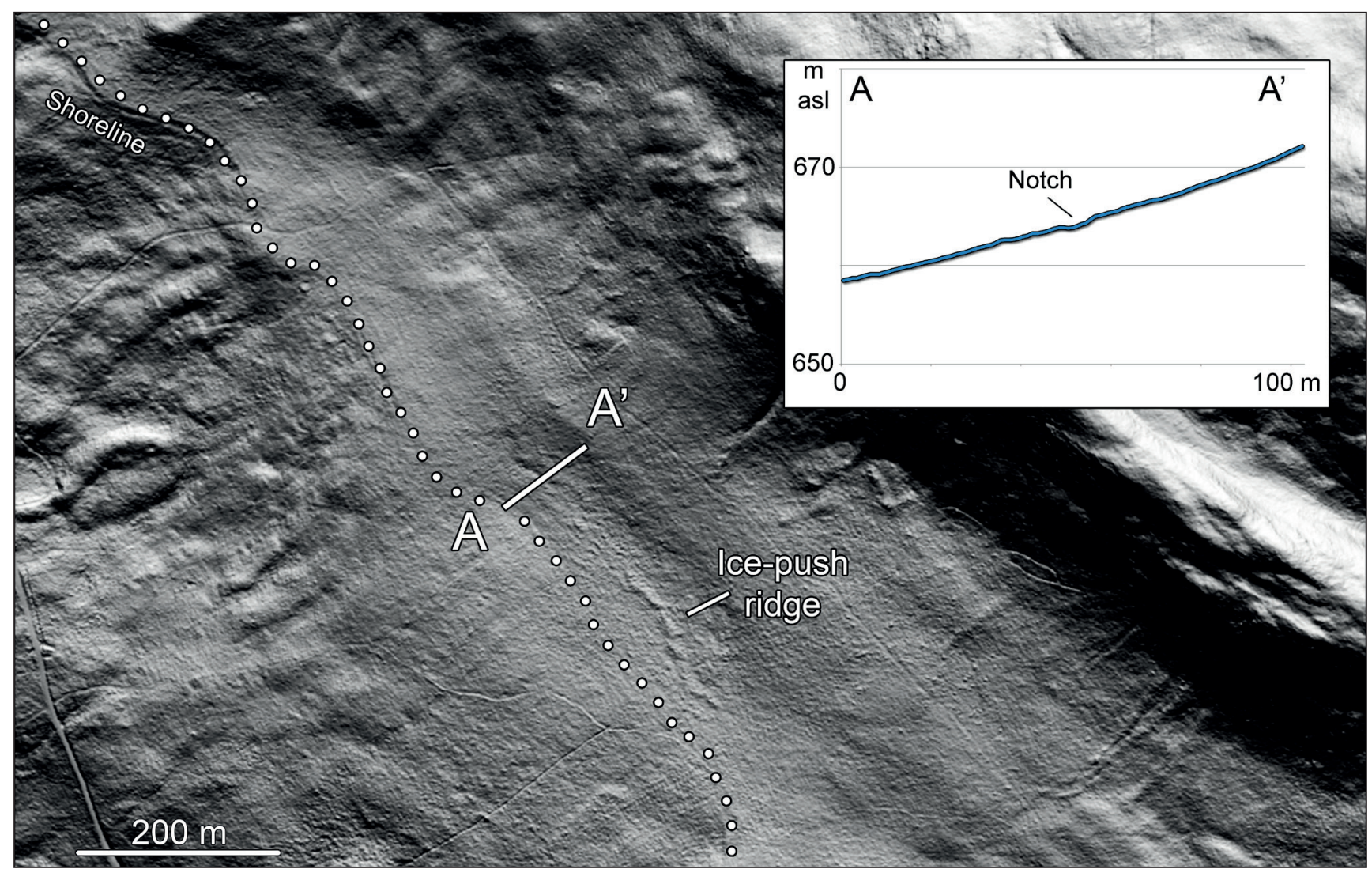

Figure 8. Near-shore ice-push notch and ridge. The approximate shoreline position is indicated with a dotted line. The delicate ice-push features are located c. 4-6 $\mathrm{m}$ above the shoreline level at $c .660 \mathrm{~m}$ asl. 


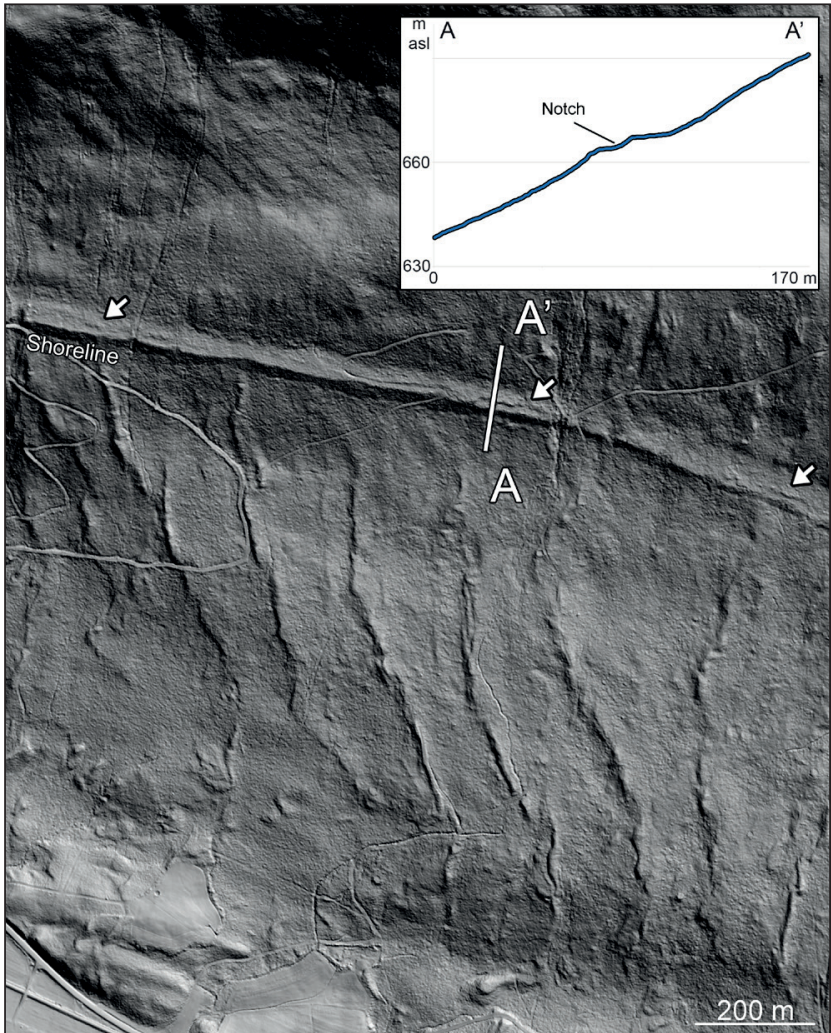

Figure 9. Hillshade image showing ice-push notches (arrowed) on the Nedre Glomsjø shoreline. The features are 0.5-2 $\mathrm{m}$ high.

marginal landforms in a region where such features previously have not been mapped, as other moraines in the region generally have been interpreted as relict landforms preserved beneath a cold-based ice sheet (Sollid \& Sørbel, 1994). Consequently, the moraines mapped in this study constitute late-glacial ice-marginal landforms situated closest to the late Weichselian icedivide.

De Geer moraines have generally been interpreted as having formed annually during winter readvances (e.g., Sollid \& Carlsson, 1984; Larsen et al., 1991; Ottesen \& Dowdeswell, 2006; Bouvier et al., 2015), whereas other studies have suggested the formation of one or more ridges every year (Lindén \& Möller, 2005; Todd et al., 2007) or even that the ridges could be of multi-annual origin (Blake, 2000). Lindén \& Möller (2005) found that an average of 2-3 summer moraines formed annually in their study area, in addition to one potential winter push moraine. If $1-3$ ridges formed annually in our study area, the ice sheet is estimated to have retreated through the area $(c .35 \mathrm{~km})$ in a matter of $60-180$ years - or roughly $600-200 \mathrm{~m} \mathrm{yr}^{-1}$ - given that the glacier did not readvance over previously deposited ridges. This is perhaps a slow retreat rate considering the extensive thinning of the ice sheet and prevailing climatic conditions at that time (Goehring et al., 2008; Hughes et al., 2016), but in accordance with other studies (Lindén \& Möller, 2005; Bouvier et al., 2015), e.g., estimated early Holocene retreat rates at the southern fringe of the ice sheet (Mangerud et al., 2018). The entire glacial lake was more than $120 \mathrm{~km}$ long, as confirmed by the presence of the Nedre Glomsjø shorelines (Holmsen, 1915). By assuming similar ice-marginal retreat rates throughout the region and using a simplified north to south recession, the ice sheet retreated through the entire Nedre Glomsjø basin in 200-600 years.

\section{Nedre Glomsjø - a vast, open glacial lake}

The landform record (Fig. 12) indicates that the region was occupied by an open ice-dammed lake, at very least in the final stages of the lake's existence. De Geer moraines fingerprint a water-terminating ice margin (Lindén \& Möller, 2005), which establishes the presence of a water body corresponding to the Nedre Glomsjø shorelines. This apparent yet previously undescribed moraine-shoreline relationship (Figs. $3 \& 5$ ) contests the theories of shorelines being subglacial or lateral meltwater features carved into surficial deposits along or beneath a stagnant ice sheet (cf., Reusch, 1917; Gjessing, 1960; Follestad, 1997, 2003).

The shorelines started to form immediately beyond the receding ice margin. Our mapping (Fig. 2) shows that the lake was larger within our study area than Holmsen (1915) suggested (Fig. 1). The De Geer moraines show that there was a stepwise, continuous retreat of the ice margin through our study area and the glacial lake's shorelines were thus formed time-transgressively. This may serve to explain the sloping nature of the shoreline platforms, as the areas that became ice-free first were subjected to glacial isostatic adjustment for a longer period compared to areas farther south.

Raised shoreline features along the Norwegian coast provide an analogue to our inland shorelines. Coastal abrasion lines or platforms rarely exceed $10 \mathrm{~m}$ in width, which is considerably less than the ice-lake's shorelines. Exceptions do exist, however, such as the prominent Younger Dryas Main Shoreline (Reite, 1967; Rasmussen, 1981; Høgaas \& Sveian, 2015). Here, erosion by abundant sea ice and extensive weathering in a tidal zone is widely regarded as the abrasion lines' forming agents (Andersen et al., 1982). The inland shorelines are too likely to be a product of various processes. Hansen $(1886,1890)$ did not emphasise wave action as a significant contributing agent, but proposed that icebergs broke off the glacier and scoured along the shore to form the shorelines, and also adopted Keilhau's (1838) early theory of annually drifting sea-ice cover as an important contributor. We partly agree with the authors' assessments and believe the steady scouring of stacked and moving sea-ice contributed into producing a final shoreline, but still emphasise wave action as the main formative agent. Prolonged erosion on approximately the same level is probably why the inland shorelines are more prominent 


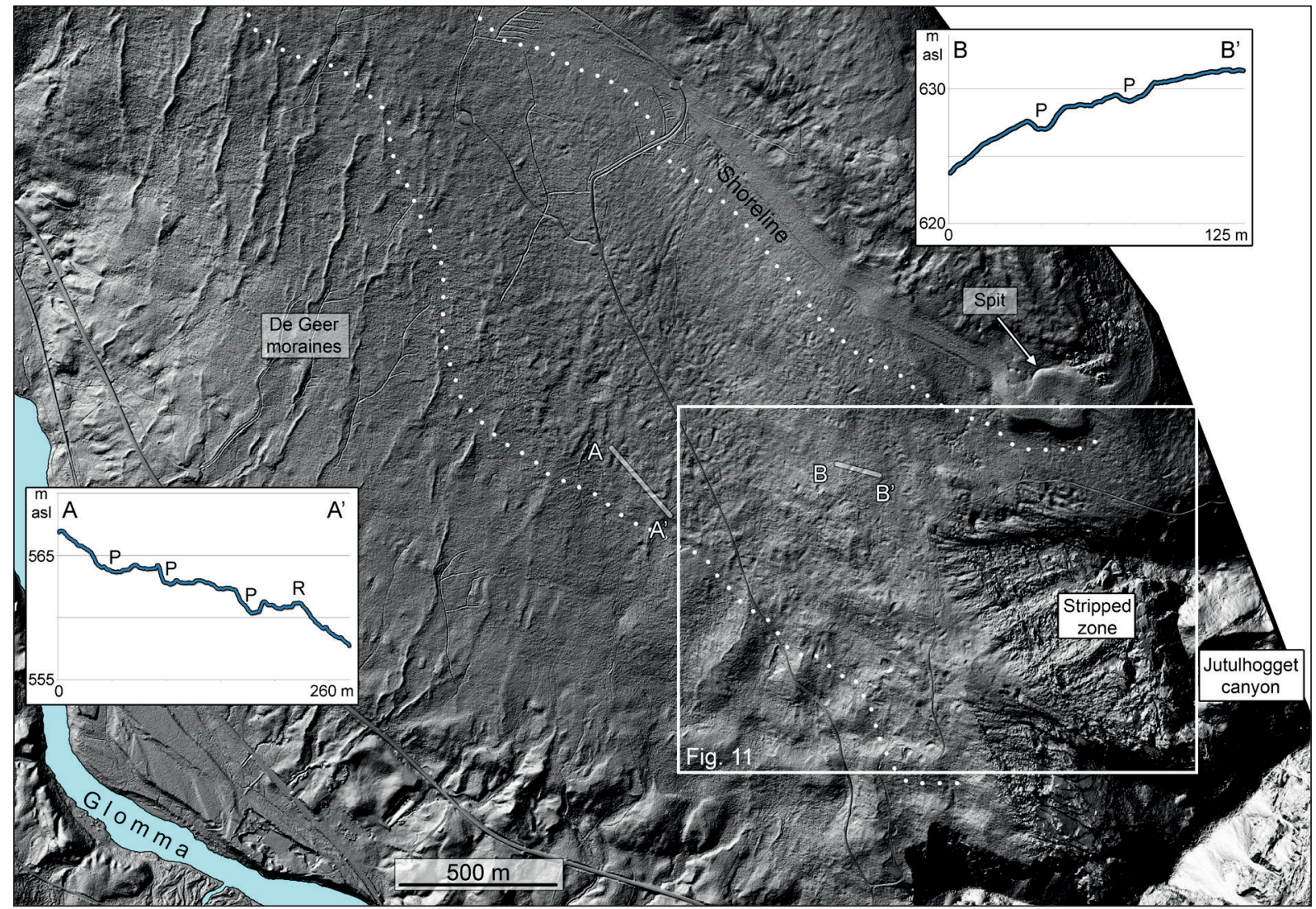

Figure 10. Hillshade image showing a zone of iceberg pits $(P)$ in the terrain near Jutulhogget, as outlined by dotted line. The depressions indicated in the terrain profiles are 1-3 $\mathrm{m}$ deep. Except for some very coarse boulder deposits, the ragged bedrock terrain closest to the canyon is completely stripped of sediments.

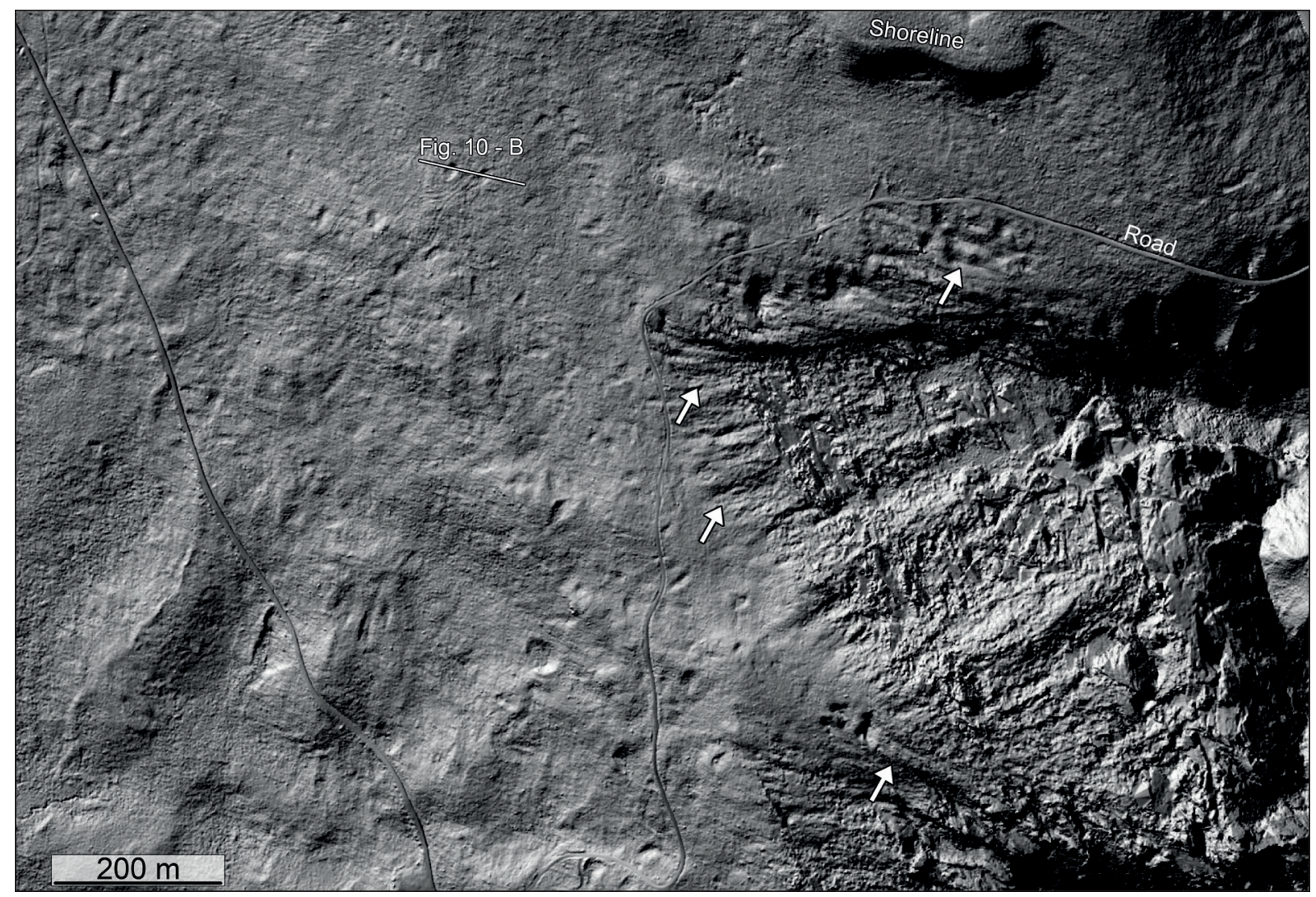

Figure 11. Hillshade image showing chaotic, pitted terrain and groove and ridge-like features (arrowed) near Jutulhogget. The grooves and ridges form a funnel-like pattern which we believe depicts the drainage pattern across the Jutulhogget massif. Boulder ridges on the stripped bedrock zone align with the obstacle marks. 
than abrasion lines formed along the coast, which were subject to continuous glacioisostatic uplift. Delicate ice-push features seen on the shoreline platforms support the presence of lake-ice within the basin and our interpretation of its contribution in forming the shorelines. The large number of beach ridges determine ice-free periods and contest the idea of minor and temporary ponding along an ice margin (cf., Reusch, 1917; Follestad, 1997) further, as the gravel berms require open stretches of water in order to form as a result of wave action.

An open lake is a prerequisite for icebergs to be pulled toward and get stuck near the Jutulhogget canyon. As the ice-dam broke, large icebergs were carried toward Jutulhogget, which was the outlet for the glacial lake's largest sub-basin. Most of the icebergs were carried through the canyon and farther downstream toward the ice margin, but some stranded and subsequently created pits and/or ice-block obstacle marks. The stripped bedrock zones, ice-block obstacle marks and funnel-like appearance of the landform record near Jutulhogget, reinforces previous studies (e.g., Longva, 1994; Berthling \& Sollid, 1999) suggesting that a sudden drainage event took place across the massif surrounding the canyon. Iceblock obstacle marks have been regarded as diagnostic indicators of jökulhlaups elsewhere and require highenergy floods in order to form (Russell, 1993; Fay, 2002; Russell et al., 2006; Burke et al., 2010). The features would not have been present in the case of a more controlled drainage event.
Lastly, the outburst flood itself demonstrates the presence of a large water body in the region. The landform record seen south of the remnant ice sheet requires a very large flood in order to form (Longva, 1994; Høgaas \& Longva, 2016) and smaller lakes along the ice margin would not have been able to sustain a sufficiently large amount of water. Based on mapping of flood deposits and erosive levels, Longva (1994) estimated that a water magazine in excess of $75 \mathrm{~km}^{3}$ was needed to recreate a sufficiently large flood, and consequently noted that much of the $c$. $100 \mathrm{~km}^{3}$ large Nedre Glomsjø basin thus had to be an open glacial lake.

The formation of open lakes occurred gradually. Most studies have engaged a rigid approach as to whether the large inland lakes existed or not and have thus failed to communicate the dynamic and rapidly changing nature of the late-glacial landscape in the region. The ice sheet decayed rapidly at the time (Goehring et al., 2008; Hughes et al., 2016) and all suggested scenarios - from 'closed' basins filled with stagnant dead-ice to open lakes - were plausible and likely as the region became increasingly ice-free. Large esker systems reveal that subglacial waterways transported large amounts of material toward the ice margin prior to deglaciation of the local and regional water divides (Sollid, 1964), while 'hanging' meltwater channels testify to lateral erosion alongside a thinning ice sheet (Mannerfelt, 1945; Olsen et al., 2013). Esker systems truncated by the Nedre Glomsjø shoreline (Fig. 6), however, determine that this phase occurred prior to the main glacial lake phase. At the time, smaller lateral lakes developed along the ice margin and,

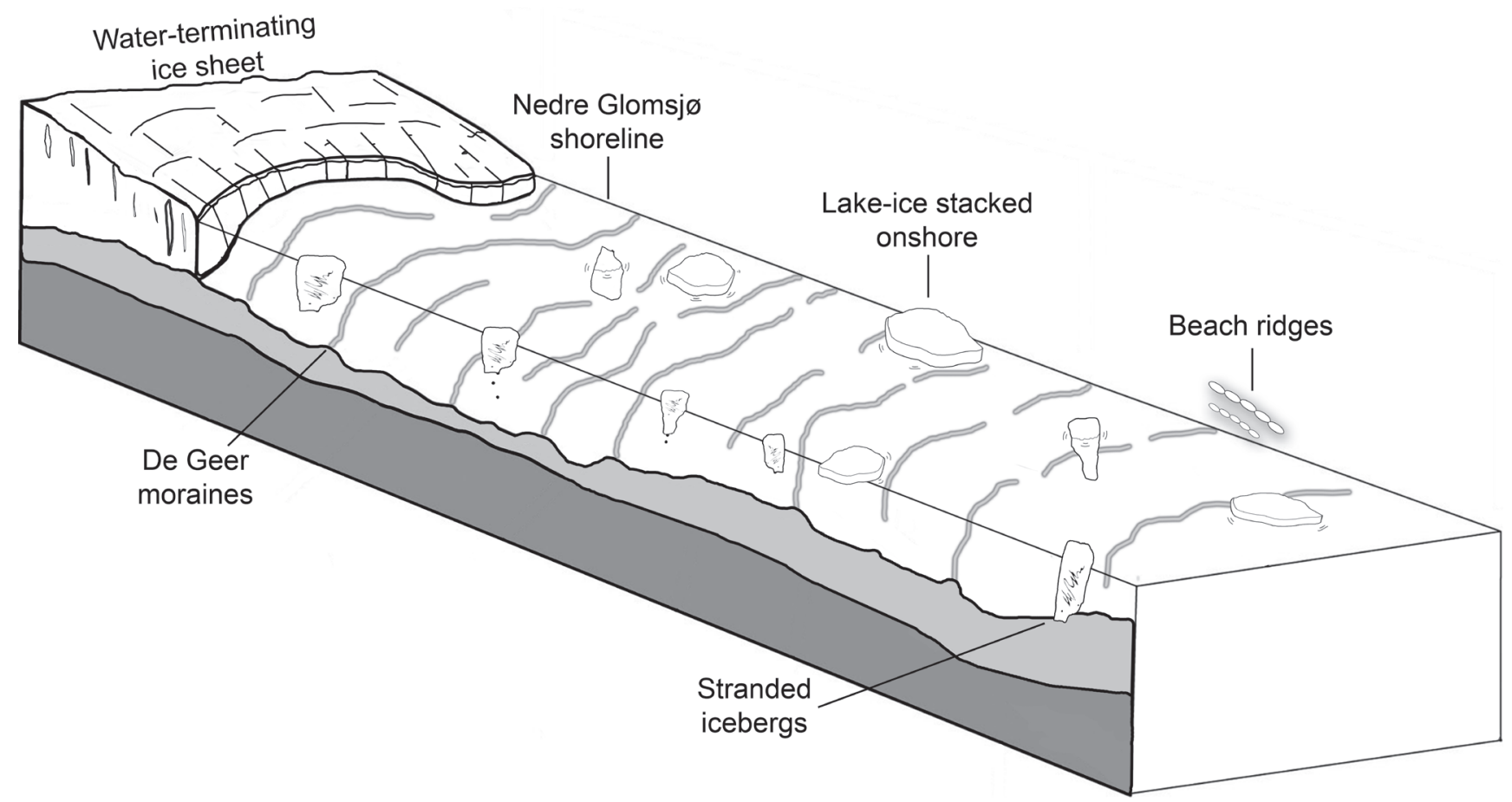

Figure 12. Landform model representative for the ice-sheet recession in our study area. 
as the regional spillways emerged from the ice sheet, increasingly larger proglacial lakes formed (Holmsen, 1915). When the ice sheet receded to the lower, deeper parts of the Glomdalen valley, glacial lake Nedre Glomsjø formed beyond a calving ice margin retreating actively southward. Large bodies of dead-ice probably resided in the valley for a long time (e.g., Andersen, 1969). The lack of signs of subaerial erosion near and at the enigmatic spillway at Rugldalen may, for instance, be explained by the presence of dead-ice, but the nature of the glacial lake's outlet is not fully understood.

\section{Outlining relative deglaciation history using traces of glacial lakes}

In a sector where the ice sheet is terrestrially based, relevant dating material is scarce and a lack of moraine ridges hamper ice-sheet margin reconstruction, traces of glacial lakes provide the best way of outlining the relative deglaciation history (e.g., Jansson, 2003). A comprehensive mapping of shoreline levels and potentially corresponding De Geer moraines will yield important information on late Weichselian ice-sheet margin positions and narrowing of the ice-divide in the large inland valleys. Seen in relation to striation marks and glacial drift landforms, traces of glacial lakes may also reveal the migration route of the late Weichselian ice-divide. As demonstrated in this study, airborne LiDAR data form an unprecedented basis for mapping relevant landforms, and can, e.g., be further used for linking ice margins to lower-lying, younger shoreline levels (e.g., Berthling \& Sollid, 1999) seen in the region.

\section{Conclusions}

- De Geer moraines indicate that a water-terminating, calving ice sheet retreated actively southward through the region rather than just melting vertically down.

- We suggest that the ice sheet retreated through our study area in $60-180$ years - or 600-200 $\mathrm{m} \mathrm{yr}^{-1}$.

- The apparent relationship between De Geer moraines and shoreline platforms shows that the retreat took place in a large open water-body; glacial lake Nedre Glomsjø. Beach ridges mapped along the glacial lake's margin confirm the former presence of large stretches of open water.

- Icebergs stranded and formed pits in the substrate near the Jutulhogget canyon as the flood waters flowed toward Rendalen. Ice-block obstacle marks close to Jutulhogget form a funnel-like drainage pattern directed towards the canyon, revealing a sudden emptying of the lake rather than a controlled event.
- A comprehensive mapping of shoreline levels and corresponding De Geer moraines throughout the region may reveal the nature of ice-sheet decay in the large inland valleys.

Acknowledgements. We thank Gustaf Peterson and one anonymous reviewer for helpful and constructive comments.

\section{References}

Andersen, B.G. 1969: Bresjøavsetninger ved Tynset i Østerdalen. Norsk Geologisk Tidsskrift 49, 289-311.

Andersen, B.G., Bøen, F., Rasmussen, A., Rokoengen, K. \& Vallevik, P.N. 1982: The Tjøtta glacial event in southern Nordland, North Norway. Norwegian Journal of Geology 62, 39-49.

Berthling, I. \& Sollid, J.L. 1999: The drainage history of glacial lake Nedre Glåmsjø, southern Central Norway. Norsk Geografisk Tidsskrift - Norwegian Journal of Geography 53, 190-201. https://doi.org/10.1080/002919599420785.

Blake, K.P. 2000: Common origin for De Geer moraines of variable composition in Raudvassdalen, northern Norway. Journal of Quaternary Science 15, 633-644.

https://doi.org/10.1002/1099-1417(200009)15:6<633::AIDJQS543>3.0.CO;2-F.

Blytt, A. 1891: Kalktuffen ved Leine. Naturen 15.

Bouvier, V., Johnson, M.D. \& Påsse, T. 2015: Distribution, genesis and annual-origin of De Geer moraines in Sweden: insights revealed by LiDAR. Geologiska Föreningens i Stockholm Förhandlingar 137, 319-333.

Burke, M.J., Woodward, J. \& Russell, A.J. 2010: Sedimentary architecture of large-scale, jökulhlaup-generated, ice-block obstacle marks: Examples from Skeiðarársandur, SE Iceland. Sedimentary Geology 227, 1-10. https://doi.org/10.1016/j.sedgeo.2010.03.001.

De Geer, G. 1888: Om Skandinaviens nivåförändringar under qvartärperioden. Geologiska Föreningens i Stockholm Förhandlingar 10, 366-379. https://doi.org/10.1080/11035898809444216.

De Geer, G. 1890: Om Skandinaviens nivåförändringar under qvartärperioden. Geologiska Föreningens i Stockholm Förhandlingar 12, 61-110. https://doi.org/10.1080/11035899009442248.

Dionne, J.-C. 1979: Ice action in the lacustrine environment. A review with particular reference to subarctic Quebec, Canada. EarthScience Reviews 15, 185-212. https://doi.org/10.1016/0012-8252(79)90082-5.

Dionne, J.-C. 1992: Ice-push features. The Canadian Geographer/Le Géographe canadien 36, 86-91. https://doi.org/10.1111/j.1541-0064.1992.tb01122.x.

Fay, H. 2002: Formation of Ice-Block Obstacle Marks during the November 1996 Glacier-Outburst Flood (Jökulhlaup), Skeiðarársandur, Southern Iceland. In Martini, I.P., Baker, V.R. \& Garzon, G. (eds.): Flood and Megaflood Deposits: Recent and Ancient Examples, Special publication of the International Association of Sedimentologists 32, Blackwell Science, pp. 85-97. https://doi.org/10.1002/9781444304299.ch6.

Follestad, B.A. 1997: Preliminary report on the research project: Upper and Lower Glomsjø - subglacial waterways or open lakes? Norges geologiske undersøkelse Bulletin 433, 50-51.

Follestad, B.A. 2003: Development of minor late-glacial ice domes east of Oppdal, Central Norway. Norges geologiske undersøkelse 441, 39-50. 
Follestad, B.A. \& Thoresen, M. 1999: Geologiske severdigheter langs bil- og sykkelveier og turstier i Alvdal. Med kvartærgeologisk kommunekart i, scale 1:60,000, Norges geologiske undersøkelse, Gråsteinen 4 (in Norwegian).

Gjessing, J. 1955: Orientering om noen isavsmeltingsstudier som er i gang i Østlandets fjelltrakter. Norsk Geologisk Tidsskrift 35, 187197.

Gjessing, J. 1960: Isavsmeltingens drenering, dens forløp og formdannende virkning i Nordre Atnedalen - med sammenlignende studier fra Nordre Gudbrandsdalen og Nordre Østerdalen. Ad Novas 3, 492 pp.

Gjessing, J. 1965: Deglaciation of Southeast and East-Central South Norway. Norsk Geografisk Tidsskrift - Norwegian Journal of Geography 20, 133-149.

https://doi.org/10.1080/00291956508551837.

Goehring, B.M., Brook, E.J., Linge, H., Ralsbeck, G.M. \& Yiou, F. 2008: Beryllium-10 exposure ages of erratic boulders in southern Norway and implications for the history of the Fennoscandian Ice Sheet. Quaternary Science Reviews 27, 320-336. https://doi.org/10.1016/j.quascirev.2007.11.004.

Hansen, A.M. 1886: Om seter eller strandlinjer i større høider over havet. Archiv for Mathematik og Naturvidenskab 10, 329-352.

Hansen, A.M. 1890: Strandlinje-studier. Archiv for Mathematik og Naturvidenskab 14, 254-343.

Hansen, A.M. 1892: Strandlinje-studier. Archiv for Mathematik og Naturvidenskab 15, 1-96.

Hillestad, G. 1991: Seismiske målinger Jutulhogget, Hedmark. Norges geologiske undersøkelse Report 91.143, 12 pp. (in Norwegian).

Holmsen, G. 1915: Brædæmte sjøer i Nordre Østerdalen. Norges geologiske undersøkelse 73, $211 \mathrm{pp}$

Holmsen, G. 1943: Jutulhogget. Naturen 6, 179-188.

Holmsen, G. 1956: Røros. Beskrivelse til kvartærgeologisk landgeneralkart. Norges geologiske undersøkelse 198, 53 pp. (in Norwegian).

Holmsen, G. 1960a: Written discussion note after J. Gjessing's talk in the Geological Society of Norway's meeting March 3rd 1960. Norsk Geologisk Tidsskrift 40, 169-171.

Holmsen, G. 1960b: Østerdalen. Beskrivelse til kvartærgeologisk landgeneralkart. Norges geologiske undersøkelse 209, 63 pp.

Holmsen, P. 1949: Mere om Jutulhogget og den store morenen ved Midtskogen i Tyldalen. Naturen 5, 140-146.

Holmsen, P. 1967: Bredemte sjøer eller subglaciale avsetninger? Norges geologiske undersøkelse 255, 97-104.

Holmsen, P. \& Oftedahl, C. 1956: Ytre Rendal og Stor-Elvdal. Beskrivelse til de geologiske rektangelkart. Norges geologiske undersøkelse 194, $173 \mathrm{pp}$.

Holtedahl, O. 1960: Geology of Norway. Norges geologiske undersøkelse 208, $540 \mathrm{pp}$.

Hoppe, G. 1960: Written note on J. Gjessing's (1960) doctoral thesis. Norsk Geografisk Tidsskrift 17, p. 373.

Hughes, A.L.C., Gyllencreutz, R., Lohne, Ø.S., Mangerud, J. \& Svendsen, J.I. 2016: The last Eurasian ice sheets-a chronological database and time-slice reconstruction, DATED-1. Boreas 45, 1-45. https://doi.org/10.1111/bor.12142.

Høgaas, F. \& Longva, O. 2016: Mega deposits and erosive features related to the glacial lake Nedre Glomsjø outburst flood, southeastern Norway. Quaternary Science Reviews 151, 273-291. https://doi.org/10.1016/j.quascirev.2016.09.015.

Høgaas, F. \& Sveian, H. 2015: The Younger Dryas Main Line on Leka, Norway, as determined from a high resolution digital elevation model derived from airborne LiDAR data. Geomorphology 231, 63-71. https://doi.org/10.1016/j.geomorph.2014.12.002.

Hørbye, J.C. 1855: Det erratiske Phænomen på Rigsgrænsen. Nyt Magasin for Naturvidenskaberne 8, 337-384.

Hørbye, J.C. 1857: Observations sur les Phénomenès d'erosion en Norvège. University of Oslo, 56 pp. Hørbye, J.C. 1859: Fortsatte iagttagelser over de erratiske phænomener. Nyt Magasin for Naturvidenskaberne 10, 232-261.
Jansson, K.N. 2003: Early Holocene glacial lakes and ice marginal retreat pattern in Labrador/Ungava, Canada. Palaeogeography, Palaeoclimatology, Palaeoecology 193, 473-501. https://doi.org/10.1016/S0031-0182(03)00262-1.

Keilhau, B.M. 1838: Om landjordens stigning. Nyt Magasin for Naturvidenskaberne 1, p. 231.

Larsen, E., Longva, O. \& Follestad, B.A. 1991: Formation of De Geer moraines and implications for deglaciation dynamics. Journal of Quaternary Science 6, 263-277. https://doi.org/10.1002/jqs.3390060402.

Liestøl, O. 1956: Glacier dammed lakes in Norway. Norsk Geografisk Tidsskrift - Norwegian Journal of Geography 15, 122-149. https:// doi.org/10.1080/00291955608542772.

Lindén, M. \& Möller, P. 2005: Marginal formation of De Geer moraines and their implications to the dynamics of grounding-line recession. Journal of Quaternary Science 20, 113-133. https://doi.org/10.1002/jqs.902.

Longva, O. 1984: Romeriksmjelen danna ved ein storflaum på Austlandet for vel 9000 år siden. Norges geologiske undersøkelse Årsmelding 1984, 8-11 (in Norwegian).

Longva, O. 1994: Flood Deposits and Erosional Features from the Catastrophic Drainage of Preboreal Glacial Lake Nedre Glàmsjø, SE Norway. PhD thesis, University of Bergen, Department of Geology.

Lundqvist, J. 1972: Ice-lake types and deglaciation pattern along the Scandinavian mountain range. Boreas 1, 27-54. https://doi.org/10.1111/j.1502-3885.1972.tb00142.x.

Mangerud, J., Birks, H.H., Halvorsen, L.S., Hughes, A.L.C., Nashoug, O., Nystuen, J.P., Paus, A., Sørensen, R. \& Svendsen, J.I. 2018: The timing of deglaciation and sequence of pioneer vegetation at Ringsaker, eastern Norway - and an earthquake-triggered landslide. Norwegian Journal of Geology 98, 301-318.

Mannerfelt, C.M.S. 1945: Några glacialmorfologiska formelement - och deras vittnesbörd om inlandsisen avsmältningsmekanik i svensk og norsk fjällterräng. Geografiska Annaler 27, 1-239. https://doi.org/10.2307/520067.

Olsen, L., Sveian, H., Bergstrøm, B., Ottesen, D. \& Rise, L. 2013: Quaternary glaciations and their variations in Norway and on the Norwegian continental shelf. Quaternary Geology of Norway 13, 27-78.

Olsen, L., Høgaas, F. \& Sveian, H. 2015: Age of the Younger Dryas ice-marginal substages in Mid-Norway - Tautra and Hoklingen, based on a compilation of ${ }^{14} \mathrm{C}$-dates. Norges geologiske undersøkelse Bulletin 454, 1-13.

Ottesen, D. \& Dowdeswell, J. 2006: Assemblages of submarine landforms produced by tidewater glaciers in Svalbard. Journal of Geophysical Research 111, 1-16. https://doi.org/10.1029/2005JF000330.

Paus, A., Velle, G., Larsen, J., Nesje, A. \& Lie, Ø. 2006: Lateglacial nunataks in central Scandinavia: Biostratigraphical evidence for ice thickness from Lake Flåfattjønn, Tynset, Norway. Quaternary Science Reviews 25, 1228-1246. https://doi.org/10.1016/j.quascirev.2005.10.008.

Pettersson, L.-E. 1997: Hydrologiske data for Mjøsa. Norges vassdragsog energidirektorat Report 6-97, 20 pp.

Rasmussen, A. 1981: The deglaciation of the coastal area NW of Svartisen, northern Norway. Norges geologiske undersøkelse Bulletin 369, 1-31.

Reite, A.J. 1967: Lokalglaciasjon på Sunnmøre. Norges geologiske undersøkelse 247, 262-287.

Reite, A.J. 1994: Weichselian and Holocene geology of Sør-Trøndelag and adjacent parts of Nord-Trøndelag county, Central Norway. Norges geologiske undersøkelse Bulletin 426, 1-30. 
Rekstad, J. 1898: Løse afleiringer i øvre Foldalen. Norges geologiske undersøkelse 28, $13 \mathrm{pp}$.

Rekstad, J. 1912: Opdæmning i Bjellaadalen ved istidens slutning. Norges geologiske undersøkelse 61, $19 \mathrm{pp}$.

Reusch, H. 1886: Vieflotten i Gudbrandsdalen. Naturen 10.

Reusch, H. 1894: Har der existeret store, isdæmmede indsjøer paa østsiden af Langfjeldene? Norges geologiske undersøkelse 54, 51-59.

Reusch, H. 1910: De formodede strandlinjer i øvre Gudbrandsdalen. Norges geologiske undersøkelse 57, $24 \mathrm{pp}$.

Reusch, H. 1917: Nogen bemerkninger i anledning av seterne i Østerdalen. Norges geologiske undersøkelse 81, 37 pp.

Rise, L., Bøe, R., Sveian, H., Lyså, A. \& Olsen, H.A. 2006: The deglaciation history of Trondheimsfjorden and Trondheimsleia, Central Norway. Norwegian Journal of Geology 86, 419-438.

Russell, A.J. 1993: Obstacle marks produced by flow around stranded ice blocks during a glacier outburst flood (jökulhlaup) in west Greenland. Sedimentology 40, 1091-1111.

https://doi.org/10.1111/j.1365-3091.1993.tb01381.x.

Russell, A.J., Roberts, M.J., Fay, H., Marren, P.M., Cassidy, N.J., Tweed, F.S. \& Harris, T. 2006: Icelandic jökulhlaup impacts: implications for ice-sheet hydrology, sediment transfer and geomorphology. Geomorphology 75, 33-64.

https://doi.org/10.1016/j.geomorph.2005.05.018.

Schetelig, J. 1910: Jutulhogget. Hvordan er det blitt til? Naturen 34, 139-145.

Schiøtz, O.E. 1891: Om Merker efter Istiden og om Isskillet i den $ø$ stlige Del af Hamar Stift, samt om Indlandisens Bevægelse. Nyt Magasin for Naturvidenskaberne 32, 243-265.

Sollid, J.L. 1964: Isavsmeltingsforløpet langs hovedvasskillet mellom Hjerkinn og Kvikneskogen. Norsk geografisk tidsskrift 19, 51-76. https://doi.org/10.1080/00291956308551807.

Sollid, J.L. \& Carlsson, A.B. 1984: De Geer moraines and eskers in Pasvik, north Norway. Striae 20, 55-61.

Sollid, J.L. \& Kristiansen, K. 1983: Hedmark fylke, kvartærgeologi og geomorfologi, scale 1:250,000, Geografisk institutt, Universitetet $i$ Oslo.

Sollid, J.L. \& Sørbel, L. 1994: Distribution of glacial landforms in southern Norway in relation to the thermal regime of the last continental ice sheet. Geografiska Annaler: Series A, Physical Geography 76, 25-35. https://doi.org/10.1080/04353676.1994.11880403.

Stroeven, A.P., Hättestrand, C., Kleman, J., Heyman, J., Fabel, D., Fredin, O., Goodfellow, B.W., Harbor, J.M., Jansen, J.D., Olsen, L., Caffee, M.W., Fink, D., Lundqvist, J., Rosqvist, G.C., Strömberg, B. \& Jansson, K.N. 2016: Deglaciation of Fennoscandia. Quaternary Science Reviews 147, 91-121. https://doi.org/10.1016/j.quascirev.2015.09.016.

Todd, B.J., Valentine, P.C., Longva, O. \& Shaw, J. 2007: Glacial landforms on German Bank, Scotian Shelf: evidence for Late Wisconsinan ice-sheet dynamics and implications for the formation of De Geer moraines. Boreas 36, 148-169. https://doi.org/10.1111/j.1502-3885.2007.tb01189.x.

Tønnesen, J.F. \& Olsen, L. 2015: Georadarmålinger og sedimentstudier for kvartærgeologisk vurdering av avsetningene ved Geitryggen og Ripan i Tynset kommune. Norges geologiske undersøkelse Report 2015.052, 18 pp. (in Norwegian).

Østeraas, T. 1977: Ripan naturreservat i Nord-Østerdalen. Miljøverndepartementet - $\AA$ s- $\mathrm{NLH}, 45 \mathrm{pp}$.

Øyen, P.A. 1899: Kontinentalglaciation og lokalnedisning. Archiv for Mathematik og Naturvidenskab 21, 62 pp. 